\title{
FOUCAULT E HEIDEGGER: MESTRES DO CUIDADO
}

\author{
Claudio Vinícius Felix Medeiros
}

Universidade Federal do Rio de Janeiro

\begin{abstract}
Resumo: Por acaso as práticas de autosubjetivação - compreendendo as "artes da existência" de Michel Foucault - forneceriam alternativas para uma ética inteiramente distinta das éticas filosóficas com base em uma adequação às categorias de uma verdade moral amparada na natureza humana, na natureza de Deus, na natureza de acordos organizados em torno de uma ideia de "bem" da sociabilidade, na natureza de regras de sociabilidade antecipadas pelos pressupostos da comunicação cotidiana? Através do cotejo entre o conceito de "cuidado" em Heidegger, como estrutura que preserva a abertura do ser-aí para a confrontação com o seu caráter essencial de poder-ser, e o "cuidado de si" em Foucault, espécie de revitalização da prática filosófica que remete a "educação para a política" a certas "relações de si para consigo", pretendemos introduzir os traços de uma ética filosófica que não cessou de dever tributos a Heidegger na tradição que constituiu a filosofia francesa do pós-guerra.
\end{abstract}

Palavras-chave: Michel Foucault; Martin Heidegger; Ética.

\begin{abstract}
Are the practices of subjectivation - including Michel Foucault's "arts of existence" alternatives to an ethic entirely distinct from philosophical ethics based on an adequacy to the categories of a moral truth supported by human nature, by God's nature, by the contracts organized around the idea of "good" of sociability, by nature of sociability rules anticipated by the presuppositions of the communication? Through the comparison between Heidegger's concept of "care", as a structure that preserves the openness of there-Being to the confrontation with his essential character of potentiality-forBeing, and the Foucault's concept of "Care of the Self", a kind of revitalization of philosophical practice that refers "education to politics" to a certain "self-relations to itself," we intend to introduce the characteristics of a philosophical ethic that was influenced by Heidegger in the tradition that constituted contemporary French philosophy.
\end{abstract}

Keywords: Michel Foucault; Martin Heidegger; Ethics.

\section{Introdução}

Há uma tendência nas entrevistas em que Michel Foucault é chamado a falar retrospectivamente do seu trabalho, que é apresentar seu pensamento como uma trajetória ao longo da qual novos eixos de análise são conquistados para, num movimento de atualização, serem rearranjados ou incorporados aos anteriores. Há uma curiosidade teórica que costura sua filosofia e, de forma ou de outra, se mantém ao largo da riqueza de temas: o tema das relações entre verdade e sujeito. Embora seja esta questão não pouco tradicional na filosofia continental, as precauções de método que preparam sua experiência de escrita não a faz derivar para uma filosofia do sujeito - com uma concepção de sujeito 
transcendental subdeterminado, por exemplo, servindo de ancoradouro para o agir moral, ou como uma antropologia, ou um positivimo lógico etc -, nem para uma "verdade" pensada como objeto a ser analiticamente conduzido pela conceituação articulada em sistemas de representações.

O primeiro eixo da trajetória filosófica de Foucault se chama "história da verdade". Trata-se de uma história das práticas discursivas que constituíram o sujeito das ciências humanas como objeto possível de saber. O que Foucault faz em As palavras e as coisas (1966) é se reportar ao solo epistemológico sobre o qual foi possível não somente dizer a verdade sobre o sujeito, mas sobretudo promover a status de "problema" a verdade requerida por uma sociologia, uma psicologia, uma antropologia.

Uma segunda fase empreende o que ele chama de "história política da verdade", e ainda aqui encontramos um estudo dos "jogos de verdade", mas agora reportados às relações de poder: práticas punitivas, práticas terapêuticas de encerramento dos loucos, práticas governamentais de exercício da soberania tendo uma população como alvo. É manifesto como daí se desencadeia a desativação da cisão entre o sujeito e o objeto própria de uma torrente científica que se seguiu aos trabalhos de Descartes e Newton, ou já no que se costuma chamar de revolução copernicana. Segundo Foucault, a emergência de regimes empíricos das ciências humanas - envolvendo o aparecimento de objetos novos, métodos novos e critérios de demarcação científica do verdadeiro/falso - está atrelada a práticas, institucionais ou não, a políticas de objetivação, que fundam regiões de empiricidades dedicadas ao sujeito louco, ao sujeito delinquente, aos sujeitos de sexualidade. Sem querer avançar para além de índices, seria importante compreender a circularidade implicada no que Foucault denomina saber-poder, e o que esta circularidade tem a ver com a lugar do discurso das ciências humanas na moderna produção de algumas figuras da subjetividade. $\mathrm{Na}$ constituição de saberes de tipo clínico, por exemplo, nos saberes com vocação para a observação como a criminologia, a psiquiatria do séc. XIX ou a psicologia do eu, esteve em jogo um tipo de saber sobre o sujeito que nasceu da observação, da vigilância, da classificação, da análise e da comparação dos comportamentos confinados.

É assim que os indivíduos sobre os quais se exerce o poder ou são aquilo a partir de que se vai extrair o saber que eles próprios formaram e que será transcrito e acumulado segundo novas normas, ou são objetos de um saber que permitirá também novas formas de controle (FOUCAULT, 2003, p.122).

O poder epistemológico que extrai do corpo submetido ao olhar panóptico um saber que fixa sua identidade, e atrela negativamente tal identidade a uma norma de comportamento sã, burguesa, eurocêntrica, é um poder cujo exercício está essencialmente assentado na fabricação, promoção, 
positivação de determinado saber. Logo: saber que produz subjetividades num duplo condicionamento com a fúria da objetivação dos corpos. Toda uma série de trabalhos publicados por Foucault ao longo da década de 1970 abre caminho para que ele quis chamar, nietzscheanamente, de genealogia do sujeito moderno.

\section{$\mathrm{O}$ objeto de todos esses empreendimentos concernentes à loucura, à doença, à delinquência, à sexualidade e àquilo de que lhes falo agora é mostrar como o par "série de práticas/regime de verdade" forma um dispositivo de saber-poder que marca efetivamente no real o que não existe e submete-o legitimamente à demarcação do verdadeiro e do falso (FOUCAULT, 2008, p.225).}

Após o período ocupado com técnicas de objetivação do sujeito (reportadas a intenções políticas identificadas em procedimentos de normatização do corpo; ou no governo, conduzido por instituições do Estado, com uma modalidade de poder pensada como segurança), permanecerá, na última fase do pensamento de Foucault, o fio condutor ao qual nos referimos: a análise de práticas cuja finalidade é vincular verdade e sujeito. Como se dissesse: para além da dimensão discursiva aberta pelas ciências humanas, para além das práticas de objetivação, a história do sujeito ocidental é qualificada ademais por conteúdos éticos, por técnicas de si, diríamos, técnicas de autosubjetivação. Convém investigar "as formas e as modalidades da relação consigo através das quais o indivíduo se constitui e se reconhece como sujeito [...]: estudar os jogos de verdade em relação de si para si e a constituição de si mesmo como sujeito" (FOUCAULT, 1984, p.11).

De que modo então, perguntaríamos livremente, a nítida profusão de vitalismo de tais práticas de autosubjetivação - compreendendo as chamadas "artes da existência" de Michel Foucault - fornece alternativas para uma ética cuja base não é uma adequação às categorias de uma verdade moral amparada na natureza humana, na natureza de Deus, na natureza de acordos organizados em torno de uma ideia de "bem" da sociabilidade, na natureza de regras de sociabilidade antecipadas por pressupostos da prática comunicativa cotidiana? $\mathrm{Ou}$, até que ponto o conceito de "estética da existência", conceito central no terceiro Foucault, aponta para a aproximação entre comportamentos práticos e teóricos, formulada dentro das possibilidades filosóficas abertas pela analítica existencial do ser-aí humano de Heidegger? Ou, como a constituição do sujeito ético em Foucault é tributária do gesto heideggeriano de consolidar a cisão do sujeito do humanismo? É o próprio Foucault quem fornece o argumento que justifica a aproximação dos dois pensamentos. Em uma anotação publicada postumamente, Foucault diz:

é a partir da tékhne ocidental que o conbecimento do objeto selou o esquecimento do ser. Retornemos à questão e perguntemo-nos a partir de quais tékhnai se formou o sujeito 
ocidental e foram abertos os jogos de verdade e erro, de liberdade e coerção que os caracterizam (FOUCAULT, 2006, p.634s, grifo no original)

Para Foucault, o que Heidegger faz é partir do problema do conhecimento na técnica contemporânea e do ser-aí em sua relação primária com o mundo para trazer à luz o tema do esquecimento do ser. Caberia então uma filosofia que se propusesse a estudar as condições históricas que tornaram possível os sujeitos desta relação primária com o mundo técnico. Há razões para se pensar (e neste contexto a filosofia de Foucault entraria) o "sujeito técnico" deste "mundo técnico"?

Há certo número de coisas que pretendemos elaborar aqui, não com o comprometimento de responder às perguntas acima. Quem sabe, ao menos seja possível refinar as perguntas fixando como norte comum a apresentação de duas acepções do conceito de "cuidado": o cuidado em Ser e tempo (1927), como estrutura que preserva a abertura do ser-aí para a confrontação com o seu caráter essencial de poder-ser (mesmo que o ser-aí em questão, pensado como pura possibilidade de si mesmo, requeira tanto a prévia decadência da existência aparelhada pela rede de sentidos que compõe o mundo, quanto, de outro modo, o estar aberto para si mesmo no modo de poder-ser mais próprio); e o "cuidado do si" no terceiro Foucault, espécie de entroncamento de comportamentos práticos e teóricos, revitalização da prática filosófica que remete a "educação para a política" a certas "relações de si para consigo". O que temos é um tema importante para uma ética filosófica que não cessou de dever tributos a Heidegger na tradição que constituiu a filosofia francesa do pós-guerra.

\section{O cuidado em Heidegger}

"Deve-se colocar a questão do sentido de ser" (HEIDEGGER, 2014, $\$ 2$, p.40). Apesar de sempre nos movermos na compreensão de ser, não é claro e evidente definir ser como um transcendental sobre o qual devemos silenciar, uma vez que ser não consiste em um conceito, nem em uma experiência objetificável. Em Heidegger, o histórico esquecimento da questão do ser se confunde com o surgimento da metafísica clássica, a lógica de Aristóteles afirma-se pela conceituação de um sentido de ser que depende do modo como se determinam categorias para significados dos entes. Eis que seria possível admitir que qualquer tratamento dado à questão do sentido do ser predispõe tal ou qual filosofia a certa concepção de ontologia, de modo que o projeto de uma ontologia fundamental empreendido em Ser e tempo requer precauções que nos impeçam de conferir ao ser o caráter de um ente simplesmente dado. "O questionado da questão a ser elaborada é o ser, o que determina o ente como ente, o em vista de que o ente já está sempre sendo compreendido" 
(HEIDEGGER, 2014, \2, p.41), sendo este justamente o elemento que torna visível o horizonte hermenêutico.

Definido o primado ontológico da questão do ser - posto que o ser em questão não se deixa representar por um ente específico, nem corresponde à totalidade dos entes em geral -, convém retomar a questão do sentido do ser pela análise das condições a priori de possibilidade do horizonte no seio do qual o ser em geral já sempre se faz compreensível.

Mas Heidegger nos diz que liberar "o horizonte em que o ser em geral é, de início, compreensível equivale [...] a esclarecer a possibilidade da compreensão do ser em geral, pertencente à constituição desse ente que chamamos de ser-aí1" (HEIDEGGER, 2014, \45, p.304) Como a compreensão de ser é uma determinação do ser do ser-aí humano (ou seja, já que a ele cabe não só o privégio de colocar a questão do sentido do ser, mas também, como é o ser-aí o único ente que detém o privilégio de, relacionandose com seu ser, responsabilizar-se aprioristicamente por uma certa condição onde seu próprio ser está em jogo), é preciso elaborar uma analítica existencial do ente cuja determinação essencial é a compreensão do ser, e daqui se estabelece para nós um ponto de partida.

Enquanto único ente cujo modo de ser não se confunde com a determinação dos entes simplesmente dados, o ser-aí, delimitado pela analítica existencial, nunca ontifica-se como as coisas que o circundam. De uma perspectiva ontológica, sua essência é ter de ser e, sendo, nunca encontrar-se plenamente acabado. A fala de Riobaldo no início de Grande Sertão é exemplar neste contexto: "O senhor... Mire veja: o mais importante e bonito, do mundo, é isto: que as pessoas não estão sempre iguais, ainda não foram terminadas mas que elas vão sempre mudando. Afinam ou desafinam." (ROSA, 1974, p.20-1) A compreensão que se tem de si não "termina" todas as possibilidades abertas para o ente cujo ser está sempre em jogo e cujo ser é estar sempre em jogo, quer dizer, "relacionar-se com seu ser como que com sua possibilidade mais própria”. Uma vez que o apropriar-se do seu ser é se movimentar num repertório de possibilidades abertas, previamente pavimentadas no mundo, não se pode pensar ontologicamente o homem senão a partir da existencialidade da sua existência cotidiana. Mas o sentido de existência ao qual Ser e tempo remete a essência do ser-aí humano não correponde àquele que a ontologia da tradição filosófica costumou chamar de existência. Casanova esclarece a particularidade do conceito: é que, como um existente, o ser-aí se constitui a partir de um movimento ek-stático.

1 Em todas as aparições do termo Dasein, traduzido por Marcia Sá. C. Schuback como "presença", optaremos pela alternativa "ser-aí". 
$\mathrm{Na}$ medida mesmo em que ek-siste, o ser-aí des-cerra (er-schliesst) o horizonte total, a partir do qual os entes se manifestam: na medida em que ek-siste, o ser-aí libera o mundo como campo de manifestação dos entes em geral, como espaço de abertura do ente na totalidade. Assim, o que temos aqui pode ser descrito da seguinte forma: 1) o ser-aí existe; 2) a existência traz consigo um movimento de descerramento e liberação do mundo [...]; 3) o surgimento mesmo desse horizonte torna possível a manifestação dos entes que, em seguida, vêm ao encontro do ser-aí [...]; 4) o ser-aí assume, então, um determinado modo de comportamento e [...] se determina como o que é (CASANOVA, 2015, p.91-2).

Mundo significa a abertura do ser, ou seja, a verdade no sentido do que no ser encontra-se desvelado. Quando se diz que o homem habita no mundo, não se quer tanto designar um espaço que implicaria um dentro/fora, mas um "dá-se" do qual até mesmo tal "espaço" depende das vias projetadas pelo ser-aí para ser espacializado. O mundo retém em si camadas históricas de sedimentações de sentidos constituídas, que não apenas circulam os limites do visível ou do dizível dos quais a filosofia seria porta-voz. Mundo é a unidade de uma medida ontológica própria. O homem, por sua vez, ek-siste como serno-mundo. E embora se veja em certa medida alienado em ser-para-fora, ele não é totalmente "mundano". Todavia, não sendo redutível aos fundamentos do mundo que o são familiares, o homem não é todo no mundo. Sempre jogando com o caráter de poder-ser de sua existência, o ser-aí se dispõe originariamente como jogado no mundo fáctico, precisando encarregar-se da liberdade de poder-ser no modo da propriedade ou da impropriedade. Importa neste momento, pra todo efeito, é que aquilo que marca o mundo é a impropriedade, o compartilhado, da maneira como diz Drummond no início de "Elegia 1938":

\footnotetext{
Trabalhas sem alegria para um mundo caduco,

Onde as formas e as ações não encerra nenhum exemplo.

Praticas laboriosamente os gestos universais,

Sentes calor e frio, falta de dinheiro, fome e desejo sexual (ANDRADE, 2012, p.137).
}

Não é nenhuma faculdade do entendimento que opera o desvelamento do horizonte de manifestação dos entes simplesmentes dados, ou dos outros entes que revelam o mesmo modo de ser do ser-aí. Numa primeira aproximação, e na lida cotidiana com a carência de sentido que constitui o ser-aí, a própria ideia do sujeito pensado como existência admite que, de antemão, o ser-aí orienta-se por aquilo que lhe é oferecido pelos sentidos e significados sedimentados em seu mundo fático. "O ser-aí cotidiano retira a interpretação pré-ontológica de seu ser do modo de ser mais imediato do impessoal” (HEIDEGGER, 2014, \$27, p.187). Do que resulta que quando o mundo vem ao encontro em seu desvelamento, eu me constituo junto aos outros e como os outros nos moldes do impessoal. No limite, eu "sou dado a mim mesmo" pelos outros, eu sou preliminarmente um projeto da demanda 
do impessoal. Assim, o si-mesmo do ser-aí cotidiano caracterizar-se-á forçosamente pelo existir impróprio absorvido "na gramática e na semântica fática sedimentada", tendendo "a manter na maioria das vezes essa absorção enquanto os sentidos fornecidos pelo mundo [...] retiverem a sua consistência" (CASANOVA, 2013, p.105).

Antes de circunscrever o papel do conceito de cuidado, que haverá de cercear o todo estrutural do ser-aí em sua dimensão ontológica, é necessário verificar, bem esquematicamente, na analítica do ser-aí, as categorias que compõem a relação entre o ser e seu aí. Em um texto de 1928, chamado Sobre a essência do fundamento, o filósofo trabalha este ponto de modo conciso. Dissemos que o mundo em Ser e tempo é uma totalidade de significados historicamente sedimentados. Porém, pensar mundo como espaço onde processos históricos alcançam unidade é dar a ele caráter transcendental. "Nós designamos aquilo em direção do qual (horizonte) o ser-aí como tal transcende, o mundo, e determinamos agora a transcendência como ser-no-mundo" (HEIDEGGER, 1999, p.123). Ser-no-mundo é ser um ente que se dá fenomenologicamente na transcendência, mas como "transcendência segundo certa situação hermenêutica". Logo, o conceito de transcendência (que terminologicamente envolve a postura de realizar uma ultrapassagem ou nela demorar-se) é aquilo que, em primeiro lugar, subtrai ao ser-aí as possibilidades que não se dispõem na clareira do que se apresenta ao ex da existência - e nesse sentido significamos que a existência do ser-aí implica uma antecipação em relação a si mesmo, um anteceder-se-a-si-mesmo enquanto originariamente jogado no campo das constituições de si mesmo. Contudo, sempre jogado em um mundo fático, o homem, em sua possibilidade mais própria assume certa decisão antecipadora ante o porvir, estando ele previamente entregue à atualidade segundo a qual a decisão abre uma situação nova. "A atualização só se esclarecerá mediante a interpretação temporal da decadência no 'mundo' das ocupações que nela encontra o seu sentido existencial" (HEIDEGGER, 2014, \$68, p.424): aqui, portanto, circunscrevemos o estatuto da decadência enquanto "momento" do ser-no-mundo.

Porém, transcendência não é só aquilo que oferece, de entrada, as condições de possiblidade para que o ser-aí exista em-vista-de-si-mesmo seguindo os parâmetros da mesmidade. Numa espécie de ultrapassagem, diz Heidegger,

\footnotetext{
o ser-aí primeiramente vem ao encontro daquele ente que ele é, ao encontro dele como ele "mesmo". A transcendência constitui a mesmidade (ipseidade). Mas [...] a ultrapassagem sempre se refere também, ao mesmo tempo, ao ente que não é o ser-aí "mesmo"; mais exatamente: na ultrapassagem e através dela pode apenas distinguir-se e decidir-se, em meio ao ente, quem e como é um "mesmo" e o que não o é. $\mathrm{Na}$ medida, porém, em que o ser-aí existe como mesmo - e somente nesta medida - pode ele ter um comportamento (relacionar-"se") para
} 
com o ente que, entretanto, deve ter sido ultrapassado antes disso (HEIDEGGER, 1999, p.122s).

São estes consequentemente os "momentos" que constituem a unidade do conceito de cuidado: a existencialidade; a decadência na facticidade; e a fundamentação ontológica do ente segundo as vias de um poder-ser próprio. Esboçamos a existencialidade ao apontarmos para algo como um anteceder-se-asi-mesmo no seio "do descerramento do mundo enquanto horizonte de determinação de todos os comportamentos do ser-aí humano" (CASANOVA, 2013, p.86). Simultaneamente, tomamos a imersão no mundo fático, a decadência nas malhas do impessoal, como elementos característicos da impropriedade como modo de ser cotidiano do ser-no-mundo. Mas tal como o ser-aí se movimenta aprioristicamente nas malhas da impropriedade e assim se deixa constituir como o mesmo, ele, cujo ser é definido por uma existência acossada por possibilidades existenciais, é livre seja para a impropriedade, seja para a indiferença, ou quiçá para um existir em sentido próprio. Existindo, o ser-aí relaciona-se com as coisas, com outros, com a indeterminação do seu poderser, no entanto, ele só pode ser propriamente si mesmo quando esta possibilidade é dada a ele por ele próprio. Como assim? Naturalmente, quando se fala em existir em sentido próprio não se deve entender com isso uma promessa de esclarecimento. Trata-se sim de um defrontar-se com a abertura de um espaço para a determinação da possibilidade que é o ser-aí a partir de seu poder-ser mais próprio. Como esta possibilidade nunca se cristaliza nos moldes de uma "essência humana", o singularizar-se (projetar-se para o seu poder-ser mais próprio) é justamente a conquista da indeterminação constitutiva da existência.

Com isto tentamos compor o sentido do conceito de cuidado através deste tripé conceitual, com acento no "momento" que melhor define o ente cuja tarefa ontológica é jogar com o caráter indeterminado de sua existência, etapa que tem a ver com uma "conquista do poder-ser mais próprio" do ente em questão.

O problema da fundamentação ontológica do ser-aí deve ser pensado numa relação de relativa descontinuidade com o tema da decadência. $\mathrm{Na}$ verdade, esse processo não se efetua senão através das crises do ser-aí. Vimos como, em princípio, a decadência no mundo fático constituiu o ocultamento do caráter de indeterminação do ser-aí. Na dinâmica do esquecimento de seu caráter de poder-ser, o ser-aí existe na fuga de seu modo de ser mais próprio. Heidegger denomina angústia o justo irromper da confrontação com a insignificância do mundo fático, com o qual o ser-aí se inquieta face ao obscurecimento das orientações dadas pelas significações dos entes em geral. Daí o estar ante a nadidade constitutiva do ser-aí, defrontando-se com a 
abertura do espaço para a compreensão da possibilidade que ele é a partir do seu poder-ser mais próprio. Defrontar-se com a implacável responsabilidade do ser si mesmo livre - nos parâmetro do velamento/desvelamento da verdade -, defrontar-se com o nada constitutivo do ser-aí, ou seja, o despontar do seu caráter constitutivo de indeterminado na experiência da angústia, é acompanhado necessariamente pela reconquista da finitude como a mais fundamental determinação do ser-aí. Assim, existir segundo o horizonte da finitude, antecipar-se para o instante da possibilidade iminente da morte é a concretização da dinâmica da finitude para o descerramento do caráter de poder-ser próprio do ser-aí.

Em Ser e tempo, a crise do ser-aí, no que ele ek-siste em virtude de uma singularização, sugere a constituição de um "campo histórico" onde o todo seguirá a tendência a uma reestruturação, já que, supõe-se: o que se tem no espaço histórico é um horizonte de um todo espacial comum e compartilhado. Em alguma medida o singularizar-se trará consigo a rearticulação dos outros e do espaço transformado da convivência. Uma ação singularizante se dá no mundo, e sendo mundo um espaço articulado, a ação singularizante se articularia com a totalidade da convivência. Mais exatamente: em Ser e tempo, o lugar onde se dá a relação entre ser e ente é um espaço entre, este é lugar do ser-aí. Quando se suprime esta distância (uma vez que o ser-aí é este entre ambos os espacos), ser e ente se apresentam imbricados num só plano. Trata-se de um espaço de aparição e recolhimento do que aparece. E na dinâmica de aparecer/recolher se dá a diferença - este é então o espaço da diferença. E quem apontará para a diferença ontológica é a singularização do ser-aí por meio da crise de esvaziamento dos índices de significância que põe em jogo o poder ou o potencial domínio do mundo sobre a existência.

Em outras palavras: sem a singularização alcançada na interpretação do caráter de indeterminado do poder-ser próprio, o futuro é aberto dentro de um leque de possibilidades legadas pelo passado. O singularizar-se abre no futuro uma via de negatividade, um campo de possibilidades, um possível que já não é da ordem do possível no passado. É como se Heidegger dissesse: é preciso assumir responsavelmente quem somos, seria preciso uma afeição pela responsabilidade que supere a aversão à negatividade. Se pensarmos então o mundo como fundamento histórico, e a mesmidade como o ser-aí colonizado nos parâmetros da impropriedade, a singularização deveria ser um trazer à tona a negatividade do fundamento através da conquista da carência e da indeterminação existencial do ser-aí. Ser si mesmo no modo de ser da propriedade é atuar diferindo-se do fundamento no sentido de fazer aparecer o vazio do fundamento enquanto tal, no sentido correlato de devolver a mesmidade às competências ônticas da historicidade. 
Façamos o esforço para chegarmos a Foucault. Parece-nos que o problema teórico das relações entre sujeito e verdade, isto é, a tarefa da escrita de uma genealogia do sujeito moderno, é transversalmente motivada por uma predominante inquietação que se pode qualificar de "ético-política", e este é o problema da alteridade. Em outras palavras: como o outro se contitui como outro? Como é possível desprender-se de si tendo sido, de antemão, "colonizado", tendo sido, no que há de mais elementar em seus gestos, em seu corpo, em seu discurso, objeto de poder do mesmo? Como contornar, através de resistências, contra-condutas, poderes que se querem totalizantes? De fato, o poder não se cristaliza no busto dos generais, apesar da tendência a reduzir, a abafar, a potência de uma ética criativa. Tudo se parece um pouco como o que diz Deleuze quando escreve sobre a obsessão de Foucault pelo tema do duplo. "Não é um desdobramento do Um, é a reduplicação do Outro. Não é uma reprodução do Mesmo, é uma repetição do Diferente. Não é a emanação de um EU, é a instauração da imanência de um sempre-outro ou de um Não-eu." (DELEUZE, 2005, p.105) Daí estão por emergir possibilidades que produzem rearranjos potencialmente inéditos. Em Sobre a essência da verdade, uma frase de Heidegger reconduz à nossa tentativa de convergir os dois conceitos de cuidado: "No projeto de mundo é dado um excesso de possível" (HEIDEGGER, 1999, p.144). Tentemos situar sem mais o conceito de cuidado no último Foucault.

\section{O cuidado de si em Foucault}

O ponto de partida das investigações de Michel Foucault sobre as práticas de autosubjetivação (que qualificam a constituição ética do sujeito antigo) são as aulas do curso $A$ hermenêutica do sujeito. Em 1982, o filósofo dá início a séries de trabalhos sobre alguns diálogos de Platão. Estas pesquisas, que irão acompanhá-lo até o fim da vida, são inicialmente consagradas à prática socrática do "cuidado de si" (a epiméleia heautô̂, em grego, ou a cura sui, na tradução latina). Ele nota que já na Grécia arcaica - depois, durante o momento socrático no séc. $\mathrm{V}$, e ainda nos primeiros séculos do cristianismo um princípio fundamental norteou a atitude e a vida filosóficas: a epiméleia beautoû, que adentra o período helenístico e romano em vias que, ultrapassando os muros das escolas de filosofia, darão início à fundação de uma autêntica cultura. Investido entre as relações do sujeito com a verdade, o preceito persegue fins precisos de promoção do cuidado de uma existência bela, e é prescrito em linhas gerais já na Ilíada, ou em Píndaro, esboçado segundo o critério de uma existência memorável e digna de fama, porque corajosa, porque regulada pela sophrosyne.

Ainda um pouco em sintonia com os estudos da genealogia do poder do fim da década de 1970 (dedicados ao domínio da racionalização da prática 
governamental no exercício da política), Foucault traz ao público os bastidores de sua ética filosófica ao propôr uma interpretação notável do Alcibíades de Platão. "O que está em jogo no diálogo é, pois: qual o eu de que devo ocuparme a fim de poder, como convém, ocupar-me com os outros a quem devo governar?” (FOUCAULT, 2006, p.50s) Elemento chave da emergência do cuidado de si no diálogo: um gênero de formação que o jovem com privilégios estatutários deverá atravessar para exercer uma ação política definida, que não é outra senão o governo da pólis. O cuidado qualifica um momento da juventude, momento intermediário entre o berço solene, o privilégio de nascença, e a atividade política propriamente dita de governo dos outros. "Não se pode governar os outros", diz o Sócrates de Foucault, "não se pode bem governar os outros, não se pode transformar os próprios privilégios em ação política sobre os outros, em ação racional, se não se está ocupado consigo mesmo" (FOUCAULT, 2006, p.48). O cuidado, no Alcibiades, aparece situado no cerne de uma problemática clássica, no interior de uma preocupação com a formação do jovem, no jogo entre filosofia e espiritualidade. Ele aparece vinculado, no limite, à preocupação platônica com a natureza das almas destinadas ao exercício do poder.

Retomemos: a atmosfera do Alcibiades é a condição do jovem aristocrata ambicioso, cioso de prevalecer no governo da pólis, às voltas com um dilema ético introduzido por Sócrates. Seja para "governar a si mesmo", diz Sócrates, seja para "governar a cidade" é necessário adotar, relativamente a si, certa atitude, assumir certas disposições, certa conversão do olhar para uma atitude vigilante, que, em seu conjunto, constituirão o sujeito ético. Temos uma prática de autosubjetivação que decorre da percepção de si mesmo como sujeito ético, é este acontecimento histórico-filosófico que nos atrai em Foucault. Está em jogo a excelência de uma vida filosófica que passa a depender de duas práticas ético-políticas indissociáveis: conhecimento e atenção a si; conhecimento e atenção aos outros. $\mathrm{O}$ diálogo segue um destino previsível: a insuficiência de educação de Alcibíades está vinculada à ignorância sobre como cuidar de si (eis, por tabela, uma válvula que ativa a denúncia platônica da insuficiência do projeto pedagógico de Atenas se comparado às formas pedagógicas de Esparta ou da Pérsia). A urgência do cuidado no interior do projeto político está acoplada ao déficit pedagógico dos que ascendem ao governo da pólis grega. "É este círculo [que vai] do eu como objeto de cuidado ao saber do governo como governo dos outros que, creio, está no cerne deste final de diálogo" (FOUCAULT, 2006, p.49).

Portanto, primeiramente, o "cuidado" no Alcibiades não é autoreferente. O que fornece sentido ao cuidado é o outro, o outro da vida cívica, daí decorrer que a pólis mediatiza a relação de si para consigo. Segunda 
determinação da forma do cuidado de si: seu campo de atuação não é originariamente democrático, o cuidado consigo é privilégio da juventude aristocrata a quem a vida cívica é reservada, é ao jovem de berço ilustre que o cuidado se endereça. Terceira coisa: o cuidado de si está em relação de dependência com o preceito "conhece-te a ti mesmo" porque a contemplação da verdade, da realidade metafísica da alma, deve ser precedida pela instauração de si como sujeito ético. Este último elemento exige destaque porque assume formas diferentes em outros diálogos de Platão.

Qualquer que seja o sentido de fato atribuído no culto a Apolo ao preceito délfico gnôthi seautón ${ }^{2}$, certo é, diz Foucault, que não são isoladas as situações onde Sócrates faz do "conhece-te a ti mesmo" uma "espécie de aplicação concreta, precisa e particular, da regra geral: é preciso que te ocupes contigo mesmo, que não te esqueças de ti mesmo, que tenhas cuidados contigo mesmo" (FOUCAULT, 2006, p.7). O Sócrates da Apologia, por exemplo, a despeito da acusação de Meleto, não é perseguido porque corrompe a mocidade fragilizando sua crença nos deuses, sim porque pratica uma forma de vida, ordenada pela divindade - ele bem o diz: que consiste em cuidar para que a juventude não descuide da razão, da verdade, do aprimoramento da alma ${ }^{3}$. No Laques, de modo correlato, está em jogo a formação dos jovens, mas há linhas transversais entre sujeito e verdade que sustentam certa indistinção entre ambos. O cuidado surge como aquilo através do qual se pode fazer da vida uma espécie de anunciação da verdade, o cuidado suprime a distância entre comportamentos teórico e prático. Aqui, Platão não faz seu eixo teórico se esgotar no conhecimento do inteligível, porque a verdade que ora transita do campo do conhecimento para a elaboração ética da existência é uma verdade outra, que dá forma, que dita contornos da existência do sujeito.

\section{Conclusão}

O ponto de partida do Laques é quase o mesmo que no Alcibíades, mas agora são duas figuras públicas, um político ilustre e um chefe militar, Nícias e Laques, que são chamadas a opinar sobre como se deve cuidar dos filhos

\footnotetext{
2 "Quanto ao gnôthi seautón, sempre segundo Roscher, significa: no momento em que vens colocar questões ao oráculo, examina bem em ti as questões que tens a colocar, que queres colocar; e, posto que podes reduzir ao máximo o número delas e não as colocar em demasia, cuida de ver em ti mesmo 0 que tens precisão de saber. [...] Defradas propõe outra interpretação, mas que, também ela, mostra, sugere que o gnôthi seautón de modo algum é um princípio de conhecimento de si [...]; e, quanto ao "conhece-te a ti mesmo", seria o princípio [segundo o qual] é preciso continuamente lembrar-se de que, afinal, é-se somente um mortal e não um deus, devendo-se, pois, não contar demais com sua própria força nem afrontar-se com as potências que são as da divindade" (FOUCAULT, 2006, p.6).

${ }^{3}$ Ou porque, dizem os biógrafos, foi do seu círculo de seguidores que saíram Crítias e Cármides, que participaram do regime tirânico dos Trinta.
} 
(educação, aprendizado das qualidades exigidas para a política, etc) para que eles cuidem de si próprios. O "conhece-te a ti mesmo", que tanto vale no Alcibiades quanto no Laques, seguirá duas formas bem diferentes a partir de agora.

Num caso [no Alcibiades], temos um modo de prestação de contas de si mesmo que vai à $p s y$ khé e que, indo à psykhé, designa o lugar de um discurso metafísico. No outro caso, tem-se uma prestação de contas, um "dar razão de si mesmo" que se dirige para o bíos como existência, [um] modo de existência que se trata de examinar e pôr à prova ao longo dessa própria existência. [...] Esse discurso de prestação de contas de si mesmo deve definir a figura visível que os humanos devem dar à sua vida. Esse dizer-a-verdade defronta não o risco metafísico de situar acima ou fora do corpo essa realidade outra que é a alma; esse dizer-averdade defronta agora o risco e o perigo de dizer aos homens o que precisam de coragem e o que lhes custará para dar à sua vida um certo estilo. [...] A partir desse tema primeiro, [...] uma [primeira] linha vai ao ser da alma (o Alcibiades), a outra às formas da existência (o Laques). Uma vai à metafísica da alma (o Alcibiades), a outra a uma estilística da existência (o Laques) (FOUCAULT, 2011, p.140).

Não mais descoberta de uma verdade no sujeito, não se tratará mesmo de identificar a alma com a verdade, como o objeto de discurso verdadeiro, mas, contrariamente, "dotar o sujeito de uma verdade que ele não conhecia e que não residia nele; trata-se de fazer desta verdade apreendida, memorizada, progressivamente aplicada, um quase-sujeito que reina soberanamente em nós." (FOUCAULT, 2006, p.604) Recolocando nos termos da noção de "cuidado" em Ser e tempo há paralelos: o ser-aí humano assume sobre si o cuidado que ele é em relação a si na compreensão da indeterminação constitutiva da sua existência, na conquista do desocultamento do caráter de indeterminado do ser-aí. $\mathrm{Na}$ dinâmica da singularização entendida como elaboração ética, o confronto com a negatividade constitutiva do ser-aí deriva de uma via de mão dupla entre comportamentos prático (cuidado) e teórico (conhecimento). A rede de razões que remete ao vínculo entre as filosofias de Foucault e Heidegger nos é sugerida por Casanova, em sua Eternidade frágil, em uma nota que traz a síntese do que até aqui quisemos explorar:

Michel Foucault mostra em seu livro $A$ hermenêtica do sujeito como, a princípio, "conhece-te" a ti mesmo e "cuidado de si" se corequisitam e só aos poucos vão se dissociando. Essa posição possui um correlato direto na compreensão heideggeriana do cuidado, uma vez que tal compreensão suprime a diferença metafísica entre comportamentos práticos e teóricos, mostrando o fato de que mesmo os comportamentos teóricos nos determinam em nosso ser (CASANOVA, 2013, p.102, n.92)

À guisa de anteciparmos uma conclusão, diríamos na esteira de Ser e tempo que o ser-aí, lançado no mundo fático sedimentado, projeta seu campo existencial de início e na maioria das vezes com vistas a sentidos fornecidos 
pelo mundo. Para que o domínio prescritivo da facticidade se rache e torne possível pensar algo como uma ressignificação semântica e a retomada como que de uma relação outra com o mundo, é necessário que o fundamento desponte em sua historicidade constitutiva. A confrontação com a própria negatividade do aí, com a historicidade do mundo fático, é desencadeada por uma crise singularizante que interrompa por ora a dinâmica da decadência. $\mathrm{Ou}$ seja, a retirada do mundo de sua estagnação hermenêutica fundamental, a reconquista pela supressão, por irregular que seja, da distância entre ser e podeser possibilita ao ser-aí retirar do seu poder-ser mais próprio o sentido singular de sua existência. Não será então, bem entendido, por meio de uma atividade teórica que se opera o descerramento do campo existencial no interior do qual o ser-aí pode realizar a si mesmo.

O incansável duplo metafísico teoria/prática colonizou toda uma abordagem ética para quem a ação moral seria o "pôr em prática" princípios ou normas com pretensões à universalidade. A compreensão heideggeriana de cuidado suprime esta diferença ao propôr que a singularização guiada pela ideia de finitude antecipada é a descoberta desta possibilidade insubstituível e certa da temporalidade própria do ser-aí humano. É o ser-para-a-morte quem determina a totalidade do cuidado, e é naturalmente a finitude a abertura para a singularização de um ente cujo ser está sempre em jogo e logo nunca "terminado". Novamente: reduzir a ética ao dever orientado por máximas universais realimentaria a objetivação da vida fática, porém como não há em relação ao sujeito qualquer determinação quididativa a priori, também não haverá ética transcendente possível. Ética e estética se corequisitam se então ligarmos os fios com o pensamento tardio de Michel Foucault.

$\mathrm{Na}$ história das relações entre conhecimento de si e cuidado de si, o mote para o cuidado de uma existência bela sofre na filosofia de Platão uma ramificação antecipada, diria Foucault. Platão teria inaugurado na história do pensamento tanto uma situação em que o cuidado surge em relação de dependência com o preceito do conhecimento da verdade da alma (garantindo o feliz engavetamento da ética pela metafísica no Alcibíades), quanto uma acepção de cuidado centrada no exercício de uma vida filosófica singular ("dar à vida um certo estilo" reaparecerá em contornos mais nítidos, como veremos, no socratismo cínico, como a aposta numa imanência que coordena ética e estética).

Como dizíamos no início, isso não quer dizer que a estilística da existência foucaultiana prescinda do debate sobre a verdade, mas tal como em Heidegger a verdade filosófica não será de ordem proposicional e epistemológica. A relação entre sujeito e verdade aparecerá em ambos como que mediada e mantida agora pela problemática da liberdade. Isso se nos for 
autorizado defender que a manifestação da verdade em Heidegger, pensada como desvelamento (alétheia) da negatividade dos fundamentos, é condição esperada para um modo de ser de sujeito que assuma responsabilizar-se pela liberdade de poder-ser mais próprio. Ora, caso a análise foucaultiana da coragem da verdade cínica aponte para o que seria a manifestação de uma verdade que se exterioriza na superfície da existência, justificaremos por certo a relevância do diálogo entre ambas as filosofias. Para tal, retomemos o fio da discussão, a sequência do debate entre cuidado e conhecimento de si no socratismo platônico e, em seguida, na prática filosófica cínica.

Depois do diálogo Alcibiades, o sobrinho de Péricles reaparecerá mais velho, na tomada final do Banquete. Embriagado pelo vinho e ressentido, entra gesticulando escorando-se nas coisas, instala uma polêmica amorosa envolvendo Sócrates e Agatão, faz um elogio afetado a Sócrates, explica por que evita o filósofo: tem medo de prestar contas das condições em que vive agora que ocupa um cargo público, sente vergonha porque apesar dos afazeres com a cidade ele ainda descuida de si, sente orgulho porque se novamente entrasse em linha de diálogo com Sócrates teria de admitir que nunca abriu mão de levar uma vida relaxada. A dissimulação e decadência de Alcibíades podem ser pensadas como representações do processo de recessão da vida pública em Atenas. Mas talvez a reaparição deste Alcibíades polêmico nos chame a atenção para outra coisa: ela nos ajuda a destacar o sentido do cuidado de si do socratismo platônico do Alcibiades (antecipando a triste reaparição do personagem no Banquete), do cuidado de si exercido no Laques ou, especialmente, no socratismo cínico de Diógenes. Há aí uma ruptura bastante notável entre duas formas quase opostas de exercer a relação entre o "dizer-a-verdade filosófico" (parresía) e a "prática política". Retornemos ao Alcibiades. Qual desfecho o diálogo oferece à questão?

Já sabemos que é preciso aperfeiçoar o sobrinho de Péricles para a política, para os negócios com que se ocupam os homens bons de Atenas. Mas quem são os homens bons a quem urge educar senão os "cidadãos capazes de governar" (PLATÃO, 2007, 125b, p.268)? Bem, quando cada um faz o que acha que lhe compete a cidade não é bem administrada, para que haja a amizade e concórdia seria preciso que os homens fossem mais sábios, que eles se tornassem bons, logo, capazes de governar. Porém, não seria possível "conhecer a arte que nos deixa melhores, se não soubéssemos o que somos" (PLATÃO, 2007, 129a, p.275). Conhecendo-nos, diz Sócrates, estamos em condições de saber como cuidar de nós mesmos. "É a alma, portanto, que nos recomenda conhecer quem nos apresenta o preceito: Conhece-te a ti mesmo." (PLATÃO, 2007, 130e, p.279) O jovem deve aprender o que é preciso conhecer antes de ser iniciado na política: conhecer a verdade filosófica sobre a 
essência das coisas. Conhecer a natureza da alma, vergar a alma de modo a fazê-la contemplar a si em sua divindade essencial é ser filósofo. Seguindo esta orientação, em seu desdobramento, "o diálogo do Alcibiades mostra, ou melhor, efetua o que se poderia chamar de 'recobrimento' propriamente platônico, recobrimento da epiméleia beautoû pelo gnôthi seautón (do cuidado de si pelo conhecimento de si)" (FOUCAULT, 2006, p.507s). Mas ainda, o que faz o cuidado de si, entendido como pedagogia, submetido ao conhecimento da alma, é justificar uma identificação, aliás fundamental em Platão, do sujeito que filosofa com o sujeito que exerce o poder.

Haja ou não recobrimento do cuidado pelo conhecimento (Alcibíades); tenha o cuidado fins ligados à constituição da existência como objeto estético, ou seja, como objeto de uma experiência estética sustentada por um "dizer-averdade" definido como "livre coragem pela qual você se vincula a si mesmo no ato de dizer a verdade" (FOUCAULT, 2010, p.64) (Laques); importa marcar é que, em Platão, o modo de ser do sujeito que filosofa deve ser o modo de ser do sujeito que exerce o poder. Não é portanto fazer coincidirem enunciação do saber filosófico e aquilo que deve ser a prática política, nem de sujeitar a racionalidade política às competências da filosofia.

\begin{abstract}
Onde vai ser para Platão lugar dessa relação necessária e não coincidente entre o dizer-a-verdade filosófico e a prática política? Não é a praça pública. Nesse sentido, se vocês preferirem, os cínicos ainda são homens da cidade que perpetuarão até o Império Romano essas tradições da cidade, da praça pública, etc. Para Platão o lugar dessa relação não coincidente não é a praça pública, é a alma do Príncipe (FOUCAULT, 2010, p.265).
\end{abstract}

Ou seja, com Diógenes, deparamo-nos com um novo momento das relações entre sujeito e verdade. O cinismo não se contém nesta sorte de homofonia entre a verdade e a vida vivida conforme os princípios do discurso. Política/filosofia, prática/teoria, modo de vida/liberdade de dizer-a-verdade em sua intolerável insolência, convém nomear estes opostos metafísicos justo para marcar a insuficiência de algumas categorias quando se trata de pensar a estilística da existência cínica. Para a vida filosófica cínica, não há verdadeiro cuidado de si se os princípios formulados com pretensão de verdade não forem imediatamente garantidos ou autenticados pela maneira como se vive. Eis um tema sedutor àquele que se propõe a aproximar a estética da existência, segundo Foucault, da estrutura do cuidado em Heidegger - como elemento que desvela para o ser-aí a indeterminação que impera nas possibilidades de ser em modo próprio. Caberá, por ora, a indicação de como em seu último curso no Collège de France Foucault interpreta o que se poderia chamar de constituição cínica da espiritualidade ou da vida filosófica. O cínico, Foucault dirá, 
faz da forma da existência a prática redutora que vai abrir espaço para o dizer-averdade. Ele faz enfim da forma da existência um modo de tornar visível, nos gestos, nos corpos, na maneira de se vestir, na maneira de se conduzir e de viver, a própria verdade. Em suma, o cinismo faz da vida, da existência, do bios o que poderíamos chamar de uma aleturgia, uma manifestação da verdade (FOUCAULT, 2011, p.150).

Um tanto quanto estranha a Platão, a estilística da existência cínica articulará o "dizer-a-verdade filosófico" (parresía) e a "prática política" não à maneira da pedagogia, não no corpo do rei filósofo, e sim "na forma da exterioridade, do desafio e da derrisão" (FOUCAULT, 2010, p.261). Desta estilística da existência, seria possível derivar um sentido, nada pejorativo inclusive, para a expressão recente "estetização da política". Tratar-se-ia, isso sim, de uma estetização que suporia a vigilância ética ao invés do delegar representativo; uma estética de si que seria da ordem da guarda das possibilidades éticas e não da abstenção política que se recolhe no familismo; uma postura vigilante de uma tal existência que se revelaria verdadeira antes mesmo que seu discurso precisasse satisfazê-la; uma prática política que torna inútil a cisão micropolítica/macropolítica na medida em que nega tais pressupostos de base (ela sabe que lírios não nascem das leis, que a política não se restringe às estruturas jurídicas do Estado tal como não está fatalmente esgotada nos interesses do grande capital). A "estetização da política" designaria por fim um momento em que a política ganha corpo no cotidiano, que a política é política na faticidade da existência ética; e que é justamente na interpelação cínica perpétua e dirigida, seja ela de forma coletiva ou difusa, ou num recorrente pôr em pauta certas práticas de autosubjetivação como sujeitos de verdade, que a política ganharia abertura para projetos de novos rearranjos das relações de força.

\section{Referências}

ANDRADE, C. D. de. Antologia poética. São Paulo: Cia das Letras, 2012.

CASANOVA, M. A. Compreender Heidegger. $5^{\mathrm{a}}$ ed. Petrópolis, RJ: Vozes, 2015. 2013. . Eternidade frágil: ensaio de temporalidade na arte. Rio de Janeiro: Via Vérita,

DELEUZE, G. Foucault. Trad. Claudia S. Martins. São Paulo: Brasiliense, 2005.

FOUCAULT, M. A coragem da verdade: o governo de si e dos outros II. Trad. Eduardo Brandão. São Paulo: Editora WMF Martins Fontes, 2011.

- A bermenêutica do sujeito. Trad. Márcio A. da Fonseca e Salma T. Muchail. $2^{\mathrm{a}}$ edição. São Paulo: Martins Fontes, 2006. 
- A verdade e as formas juridicas. Trad. Roberto Machado e Eduardo J. Morais. Rio de Janeiro: NAU Editora, 2003.

- História da sexualidade II: o uso dos prazeres. Trad. Maria T. da C. Albuquerque. Rio de Janeiro: Edições Graal, 1984.

. Nascimento da biopolitica. Trad. Eduardo Brandão. São Paulo: Martins Fontes, 2008.

. O governo de si e dos outros: curso no Collège de France (1982-1983). Trad.

Eduardo Brandão. São Paulo: Editora WMF Martins Fontes, 2010.

HEIDEGGER, M. Ser e tempo. Trad. Marcia Sá. C. Schuback. 9 ed. Petrópolis: Vozes, 2014.

. "Sobre a essência do fundamento" In: Os pensadores, Martin Heidegger.

Trad. Ernildo Stein. São Paulo: Ed. Nova Cultural, 1999.

MUCHAIL, S. T. Foucault, o mestre do cuidado: textos sobre a Hermenêutica do Sujeito. São Paulo: Loyola, 2011.

PLATÃO. Fedro - Cartas - O primeiro Alcibiades. Trad. Carlos A. Nunes. $2^{\text {a }}$ ed. Belém: EDUFPA, 2007.

1015. . Laques - Eutifron. Trad. Carlos Alberto Nunes. Belém: EDUFPA,

ROSA, J. G. Grande Sertão: Veredas. 9ª ed. Rio de Janeiro: Livraria José Olympio ed., 1974.

VATTIMO, G. Introducción a Heidegger. Trad. Alfredo Báez. Barcelona: Ed. Gedisa, 2002.

E-mail: claudiomedeirosrj@gmail.com

Recebido: 03/02/2017

Aprovado: $14 / 05 / 2017$ 